\title{
SENTIR Y TRANSMITIR \\ EL ARTE DE LOS MEDIADORES DE LECTURA EN CONTEXTOS DE CRISIS
}

Michèle Petit

Universidad de París I, France

Resumo: Este texto constitui-se a partir da fala de Michele Pètit proferida no seminário A experiência leitora, na Feira Internacional do livro Infantil e Juvenil (FILIJ 28) em novembro de 2008, no México. Nele, a autora propóe uma reflexáo sobre mediaçáo de leitura a partir dos dois movimentos propostos no título - sentir e transmitir. Na primeira parte, trata do desejo que sentia ao observar sua mãe lendo, o que a fazia imaginar que coisas fabulosas a mantinha durante horas diante de um livro; ou quando ouvia seu professor de grego falar de livros e tecer relaçôes que até então não havia imaginado. Assim, a partir de sua trajetória como leitora, Petit propóe que, primeiro, é a experiência leitora do outro que nos conduz à leitura e às pesquisas sobre leitura. No caso de Petit, sua pesquisa está relacionada ao interesse em ouvir a relação dos leitores com os textos. E nessa escuta, aparece o segundo eixo do texto - o transmitir -, em que menciona o trabalho de professores, bibliotecários, promotores de leitura, escritores, psicanalistas, editores e outros, que possibilitam a aproximação com os livros. E a partir dos livros, o acesso à interioridade do outro. Nesse sentido, apresenta o trabalho de mediação de leitura de Mirta Colangelo (Argentina) e de Mona Thomas (França) e, a partir deles, reforça uma imagem de leitura já afirmada em todo o texto: a leitura como uma oportunidade de encontrar-se com o outro, com as possibilidades e riscos que implica todo encontro.

Palavras-chave: mediação; leitura; leitores; outro; desejo.

Buenos días a todos, y gracias. Gracias a Daniel Goldin, gracias a Mónica González Dilon, a Antonio Barquet Morales, a los otros responsables de la FILIJ y a los organizadores de este seminario por su confianza y su invitación. Gracias a Josefina Anaya, que tradujo el texto de esta conferencia. Y gracias a ustedes por su presencia.

Del tema vasto y complejo que nos reúne este año me gustaría pensar que fue escogido especialmente para mí, a la manera de esos lectores que piensan que el libro que están leyendo fue escrito justamente para ellos. A mi modo de ver, en efecto, la experiencia de la lectura es lo que he estado tratando de abordar, de alcanzar, por todas las vías que se me presentaron desde que realizo investigaciones en esta práctica. Esta curiosidad posiblemente tiene 
origen en un recuerdo. Y como Daniel me invitó a evocar también mi experiencia personal, hablaré un poco de ello a manera de introducción.

\section{Al principio fue la experiencia del Otro...}

Tengo quizá ocho o nueve años y veo a mi madre sumergida en un libro, o en hojas que cubre de palabras. Menos precisa es la imagen de mi padre, cautivado también por el soporte impreso que tiene entre las manos. Los dos fueron grandes lectores, curiosos de todo; y mi madre lo sigue siendo, a los 87 ańos. En mi memoria, de vez en cuando levanta la cabeza del libro que está leyendo, o del que está escribiendo, con la mirada perdida a lo lejos, muy lejos de mí. Esa obra a la que parece estar tan íntimamente ligada tiene el poder de llevarla a un sitio donde intensamente está viviendo algo que no sé qué es. Sus pensamientos y sus sensaciones son casi palpables, pero unos y otras me escapan. Estoy a las puertas de un mundo a cuya entrada no tengo acceso.

Había olvidado esta imagen de mi madre entregada a su ensoñación desencadenada por lo escrito. Me volvió al leer un texto donde Gustavo Martín Garzo (2001) relata un recuerdo de su propia infancia. Ya evoqué este texto en la Ciudad de México hace unos años: él también, un día, a los seis años, regresando de la escuela, encuentra a su madre en la cocina, sola, leyendo, "en medio de un círculo encantado". El chico se queda ahí parado, fascinado por la visión de su madre que, al darse cuenta de su presencia, termina diciéndole que está leyendo un libro de amores desgraciados, El caballero de los brezos. No obstante, en su rostro hay una expresión de felicidad como si le ocultara algo, algo relativo a los secretos más hondos de su vida. Ella le lee en voz alta un pasaje que describe a una joven, su cuerpo, su rostro, pero el enigma no se despeja. Varias veces, el niño va a robar El caballero de los brezos u outras novelas, para leerlas en un pequeño cuarto bajo las escaleras, sin lograr adentrarse al misterio, a sorprender en sí mismo el embeleso, la emoción, que ha visto en el rostro de su madre: "Busco esa emoción, el sentimiento de estar traspasando una frontera, pero no lo consigo.".

La experiencia lectora vivida por su madre lo esquivará mucho tiempo, y durante toda su vida sus lecturas no serán, según él, más que una tentativa de elucidar el misterio de la escena inaugural: "Esos libros son entonces el que ella estaba leyendo. Todos los libros El caballero de los brezos. Lo he tomado en secreto (de hecho durante un tiempo nada me gustó más que 
robar los libros que iba a leer) y vuelvo a estar escondido en el cuarto que había bajo las escaleras. Eso es leer para mí, estar escondido. Todos los libros son ese único libro, y yo me inclino sobre sus páginas tratando de adivinar los pensamientos de mi madre joven y hermosa.".

Al leer estas líneas recordé los días en que veía a mi madre o a mi padre leer y perderse en una ensońación y en que yo me preguntaba dónde tenían la cabeza, adónde se habían ido. Tal vez para resolver ese misterio empecé a aventurarme en los libros cuando era niña, para conocer los pensamientos de mi madre joven y hermosa, como bien lo dice Gustavo, o de mi padre joven y hermoso. Y tal vez también a eso se debió que, muchos años después, me haya convertido en antropóloga de la lectura. Mis preocupaciones infantiles se transformaron en temas de investigación: quería comprender qué es lo que desencadena el encuentro con un libro o un fragmento de texto.

$\mathrm{Al}$ principio fue, pues, la experiencia lectora del Otro, en este caso de mi madre, a veces de mi padre, y fue un misterio tanto más fascinante cuanto que, al igual que el joven Martín Garzo, sentía que atañía al cuerpo, a las emociones, al deseo. Por lo demás, por "experiencia" suele entenderse el hecho de experimentar, de sentir algo (estamos de entrada del lado del cuerpo) y de verse transformado, en mayor o menor medida. Porque después de una experiencia ya no seríamos exactamente los mismos, habríamos adquirido un conocimiento - con lo que este término sugiere de iniciático - más que un saber - que puede ser objetivo y enseñarse.

Tengo la impresión de que en verdad sentí, o más bien imaginé, o fantaseé, cuando era nińa, y más aún adolescente, esta dimensión iniciática ligada a la experiencia, a cualquier experiencia. Por ejemplo, durante los años en que fui scout, donde existía un rito llamado de totemización, durante el cual una noche, después de algunas pruebas un poco sádicas, le conferían a uno el nombre de un animal. Todas las noches del verano, al acostarme, temía que me despertaran y que tuviera que pasar por dicho rito, y los que lo habían "pasado" me fascinaban como si a partir de entonces ya fueran de una naturaleza diferente. Experimentaba esta fascinación todavía más por aquellas y aquellos que, un poco mayores, estaban iniciados ya en el amor carnal: también estaban del otro lado de la barrera, de la frontera. Ellos sabían. ${ }^{1}$ Frente a quien había vivido lo que yo ignoraba aún, yo estaba en la puerta, tal como cuando contemplaba a mi madre y a mi padre sumidos en la lectura, o soñadores después de haber apartado los ojos de su libro.

${ }^{1}$ Es posible que la fascinación de las drogas tenga que ver con esta búsqueda de un conocimiento tanto fantaseado como iniciático, al igual que la de las experiencias limítrofes. 
Quien, él o ella, se supone que tiene experiencia suscita sentimientos ambivalentes. Se le suele arrogar un poder gracias a una sabiduría, a un arte $\mathrm{o}$ a ese conocimiento adquirido por las pruebas a que se vio sometido, como si se hubiera aproximado, o hubiera visto, lo que queda velado a los ojos de los demás. Aun cuando a la mayoría de nosotros nos parezca baladí, la experiencia de la lectura puede suscitar en los no lectores tales sentimientos de envidia marcados por el temor o la rabia. Los que no la han experimentado, aquellos a los que los libros no les inspiran más que aburrimiento, se sienten excluidos de algo que se les escapa. Como el joven chofer de taxi que me dijo un día: "En la escuela, les pegábamos a quienes les gustaba leer. Creo que en el fondo era envidia: nos preguntábamos qué es lo que podía haber en los libros.”

\section{...envidiada y temida}

En la desconfianza de quienes parecen tener un vínculo casi carnal con lo escrito es posible que entren otras inquietudes, como esta que menciona Jean-Louis Baudry (2000): "Ver a alguien leer es de inmediato presumir que detenta un don que le permitirá leer en nosotros." Baudry observa también con agudeza, a propósito de sus recuerdos de la niñez:

La lectura me parecía una actividad destinada específicamente a las mujeres, como el baile, por ejemplo. Los hombres sólo tomaban parte de ellas para acercarse más directamente a las mujeres. Leer un libro permitía convertirse en galán, en caballero acompañante de placeres que eran ante todo placeres de expresión. Por otra parte la lectura era tan femenina que feminizaba a los que se dedicaban a ella, como mi padre. Los feminizaba hasta el punto de que gracias a ella podían reflejar la luz de esas virtudes que hacían resplandecer a las mujeres, virtudes asociadas al ejercicio y al dominio del lenguaje: inteligencia, sutileza, fineza, imaginación, y un don que ellas parecían poseer, el de ver más allá de las apariencias. Pero sobre todo, y quizás paradójicamente, la lectura constituía uno de los atributos de la autonomía que yo les adjudicaba.

En muchas sociedades contemporáneas las mujeres leen más que los hombres, pero, sobre todo, más bien se atribuya a las mujeres una cierta experiencia de la lectura suscitada por la literatura - aun si hay hombres que la conocen, por supuesto. En este sentido también existe la idea de un conocimiento un poco misterioso y de un goce particular en el que las mujeres descuellan, lo que sería el encanto de esta lectura para algunos y su 
índole angustiosa para otros. Manguel (1998, p. 37), en su Historia de la lectura, hace notar:

La inquietud común respecto a lo que podría hacer un lector entre las páginas de un libro se parece al temor eterno que sienten los hombres ante la idea de lo que las mujeres podrían hacer en los lugares secretos de su cuerpo, de lo que podrían realizar en la oscuridad brujas y alquimistas detrás de sus puertas cerradas con triple llave.

No es sorprendente que muchos se hayan esforzado por poner orden em estas zonas de sombra, por controlar esta experiencia: autoridades morales, religiosas, políticas, pero también investigadores y pedagogos. Se sabe que, en general, los científicos desconfían de la experiencia, imprevisible y siempre singular, aun cuando compartida en gran medida. Ellos prefieren la experimentación, repetible a voluntad, cuyo marco, desarrollo y resultados pretenden dominar. Recuerdo el asombro de mis colegas cuando les dije un día que lo que me interesaba eran las experiencias de los lectores y de las lectoras, a veces en las franjas de lo indecible, pero que tratan de encontrar forma de modo fragmentario durante una conversación o una autoficción. “¿Experiencias'? ¿No prefieres utilizar otra palabra?” Retrocedían como si hubiera pronunciado palabras obscenas, luego preguntaban, nerviosos: “¿Y cómo vas a aprehender estas 'experiencias', siguiendo qué método?” Su desconfianza redoblaba cuando les decía que iba a escuchar a las personas hablar, o leer lo que habían escrito, a prestar atención a estos actos de narración por medio de los cuales intentaban transmitir una vivencia que se resiste o se evade.

Al igual que los científicos, muchos pedagogos desconfían de la experiencia, y en este caso de lo que los lectores experimentan. Como escribe Jorge Larrosa (2003, p. 41),

[...] la pedagogía (quizá toda pedagogía) ha intentado siempre controlar la experiencia de la lectura, someterla a una causalidad técnica, reducir el espacio en el que podría producirse como acontecimiento, capturarla en un concepto que imposibilite lo que podría tener de pluralidad, prevenir lo que tiene de incierto, conducirla hacia un fin preestablecido. Es decir, convertirla en experimento $[\ldots]$

Bourdieu, por su parte, observó que la escuela destruye una cierta experiencia popular, erradica una cierta necesidad de lectura, en la que el libro es percibido como depositario de secretos mágicos y del arte de vivir, 
para crear otra necesidad, de forma diferente. En este sentido, lo que me sorprendió mucho cuando empecé a trabajar sobre la lectura fue descubrir que una parte de quienes, hombres y mujeres, están encargados de enseñar la lengua y la literatura parecían no haber tenido acceso a esta experiencia lectora personalmente, o bien la habían olvidado, perdido, reprimido. Hablaban de literatura como una persona frígida dando un discurso sobre el amor carnal. Con los libros no tenían más que una relación de dominio: el texto era algo que había que disecar con ayuda de escalpelos tomados de la crítica textual, de las teorías de la enunciación, de la retórica.

Es verdad que en Francia, quizá más que en otros países, hace ya largo tiempo que se consumó la ruptura entre el mundo de la inteligencia, de la razón, y el de la sensibilidad. En la escuela, durante mucho tiempo se estudió la literatura como algo externo a sí mismo, que no tiene que ver con las vivencias, las experiencias o las sensaciones. Algunos enfoques se han afanado en ahondar la distancia con el cuerpo, en repudiar cualquier emoción, la cual era vista como un riesgo de perderse. Y durante mucho tiempo el cuerpo ha sido lo olvidado, lo impensado en las investigaciones sobre la lectura, reducida a una actividad mental pese a que se trata de una actividad psíquica que involucra de manera indisolublemente ligada tanto el cuerpo como la mente.

Lo que se experimenta no se evalúa, supone también tiempos de silencio: quizás haya una gran dificultad para trabajar con la experiencia lectora en el espacio de la clase. No tengo la competencia para hablar de esto porque no he trabajado en el universo escolar, y otros lo harán mejor que yo. Pero me parece que al menos podría uno imaginar dispositivos para que los profesores tengan acceso por sí mismos a esta experiencia, o que no la repriman.

Traeré a colación otro recuerdo personal, el de un profesor con quien aprendí griego moderno cuando tenía yo veinte años. Es alguien cuya enseñanza cambió completamente mi vida y mi pensamiento, al igual que los de la mayoría de los que me rodeaban. Nunca nos pregunto acerca de lo que sentíamos, ni habló de lo que él mismo sentía. Por lo demás, no nos hacía ninguna pregunta sino más bien respondía siempre a las nuestras, que no eran muchas porque escucharlo nos proporcionaba pura felicidad. En su presencia, en las asociaciones sabias y poéticas que le inspiraba un texto, todo nos decía que lo vivía intensamente, con sus sentidos y su inteligencia. Elaboraba frente a nosotros un pensamiento vivo, alejado de dogmas, de sistemas rígidos. No daba muerte al texto sino que tenía con él una de las 
conversaciones más sutiles que pueda haber. Sus hallazgos del momento, sus intuiciones, se enriquecían con su erudición. Tejía mil lazos, reformulaba pensamientos anteriores, los reavivaba. Al hacerlo, agudizaba mucho nuestra sensibilidad y nuestra capacidad de pensar. Al salir de su curso veíamos el mundo con otros ojos, más intenso, más fino, y teníamos ganas de correr a leer mil libros.

\section{En busca de ecos}

Porque tuve oportunidad de toparme en el camino, desde la infancia, con personas que leían con fervor, porque excitaron mi curiosidad y porque el mundo entero me intrigaba, pasé muchas horas en los libros. Desde muy pronto sentí que entre ellos había compañeros maravillosos que me hacían reír, soñar, que me daban calor, que me embarcaban con ellos hacia tierras lejanas. En ellos descifraba secretos, indagaba sobre lo que me rodeaba y lo que yo sentía. Encontraba sitio.

Me pasé la vida rodeada de libros, pero era como una evidencia. Curiosamente, incluso cuando estuve en psicoanálisis hablé muy poco de la importancia que siempre tuvo la lectura. Con el transcurso de los años se dio, gracias a los libros, esa otra recomposición constante de mi historia, esa outra elaboración simbólica, psíquica, diferente de la inducida por la escucha de un psicoanalista, esa otra "medicina lingüística" que me acompañó siempre, ese diálogo continuo, pero eso ocurrió "naturalmente", sin que me tome el tiempo de pensar.

Fue cuando escuché a las personas contar sus recuerdos de lectura, o cuando leí obras en las que los escritores habían transcrito escenas fundadoras de su propia relación con los libros, cuando mis propios recuerdos empezaron a surgir. Escribí entonces Una infancia en el país de los libros para acercarme a lo que yo buscaba entre líneas cuando era niña, para hacer explícita esta experiencia. Al filo de las páginas que escribía me di cuenta de que esos recuerdos eran la cara oculta de mis investigaciones y que un trabajo "científico" era una autobiografía disfrazada.

Muchos lectores viven así en compañía de los libros sin preguntarse por lo que sienten, sin tratar de hacer explícita la forma en que se tejen la vida, las sensaciones, el pensamiento, la lectura. A veces dejan caer una frase que aclara un poco qué pasa entre ellos y las páginas leídas. En las entrevistas que realicé, es a estas frases a las que presté atención, para comprender 
cómo se había modificado el mundo interior gracias al encuentro con un texto, incluso con una simple frase. Para alcanzar la "subconversación" que desencadena un libro. Y en ocasiones aproximarse a lo indecible, a lo que transcurre fuera del lenguaje.

$\mathrm{Al}$ oír hablar a los lectores comprendí que las tierras desconocidas, inquietantes, a las que se aproximaban no tenían que ver más que con la parte de uno que es la más secreta, la mas singular, la mejor compartida: la de nuestros deseos, nuestras sensaciones, nuestras emociones. Medí hasta qué punto estamos en busca de ecos de lo que hemos vivido de manera oscura, confusa, y que algunas veces se revela, se explicita de manera luminosa y se transforma gracias a una historia o un fragmento. Llega a ocurrir que un desconocido, en la calle, en un café, en la televisión, pronuncie una o dos frases o cuente una anécdota que ilumina una región en nosotros que no habíamos podido expresar. No obstante, la cultura - y especialmente la literatura - prodiga ecos, recursos inigualables.

Para decir la experiencia humana, todas las sociedades han recurrido a especialistas, a "traductores" profesionales, narradores, poetas, dramaturgos, o - en distinta forma - psicoanalistas, todos los cuales trabajan lentamente, a cierta distancia. Los escritores se toman el tiempo necesario para dotar de significado a un acontecimiento individual o colectivo, a una experiencia singular y universal. Profesionales de la observación, escriben muy de cerca con un pensamiento próximo al inconsciente y sus mecanismos: la condensación, el desplazamiento. Sacuden a la lengua, la desempolvan de sus clichés. Muchas de las obras que crean han nacido del deseo de dilucidar una faceta de lo que ellos mismos han vivido. En resonancia, las palabras leídas confieren inteligibilidad e incluso alegría - más aún cuando se propone a los lectores no una copia de su propia historia sino una trasposición, un desplazamiento, una metáfora.

Los escritores saben todo esto y lo dicen mejor que nadie. Pierre Bergounioux (2002, p. 49) escribe así que:

[...] los buenos libros nombran de modo simple y sencillo las cosas que nos ocurren y nos afectan, sobre todo en la medida en que no las comprendemos verdaderamente. Al lado de la esfera del sentido común, del comentario apresurado, aproximativo, cuyo destello incierto guía nuestros pasos en el camino de cada día, existen versiones aproximadas, amplias, insólitas, deslumbrantes de nuestra experiencia: aquellas que la literatura, y sólo ella, es capaz de dar. 


\section{Un ángel que abre puertas y luego se echa a volar}

Proust (1988, p. 37), por su parte, decía de la lectura que es "la iniciadora cuyas claves mágicas nos abren, en el fondo de nosotros mismos, la puerta de las moradas donde no habríamos podido penetrar". Evoca así la figura de un ángel que abre puertas y al instante se echa a volar, momentos de gracia en los que tocaríamos la quintaesencia de la vida. Para él son los pensamientos que despierta la lectura los que la dotan de dignidad. Y se burla del letrado para quien "el libro no es el ángel que se echa a volar apenas acaba de abrir las puertas del jardín celeste, sino un ídolo inmóvil al que adora por sí mismo [...]" (PROUST, 1988, p. 37) Y prosigue: "El supremo esfuerzo del escritor como el del artista no alcanza más que a levantar parcialmente en nuestro honor el velo de miseria y de insignificancia que nos deja indiferentes ante el universo. En ese momento es cuando nos dice [...] ¡Observa! ¡Aprende a ver! Y en ese mismo instante desaparece.” (PROUST, 1988, apud LARROSA, 2003, p. 240).

Ahí donde la experiencia de la lectura tal vez sea irremplazable es cuando abre los ojos o cuando suscita ese pensamiento vivo, en movimiento, cuando hace que surjan ideas, sugiere asociaciones insólitas, inspira, despierta. El valor de la lectura son esos momentos en que surgen palabras, en que se tejen lazos, en que somos como fecundados $-y$ he aquí de nuevo a los lectores del lado de la feminidad. A esto se debe que tantos escritores lean antes de ponerse a escribir, que a tantos sabios les guste leer poesía o una novela para dar un nuevo impulso a su actividad inventiva, para que emerjan conexiones inesperadas.

Insistimos en que se trata de un pensamiento muy diferente del pensamiento racional, completamente abierto hacia el exterior, y tal vez por eso el que alza los ojos de su libro mira a lo lejos. "Siempre pensamos en otro lugar", decía Montaigne. En esos instantes pensamos afuera de nosotros, lanzados a una lejanía adonde el libro nos lleva. Este pensamiento es de una esencia diferente del que Rodin quiso representar, y del que Jean-Christophe Bailly (2007, p. 45) escribe:

El Pensador de Rodin, replegado por completo en sí mismo, corresponde a la imagen del pensamiento solicitada por una época que acababa de salir del fervor contemplativo, obsesionada por el progreso y las hazańas tangibles. En su pesadez, y hasta en la violencia con que se instaura en la presencia, dejó muy atrás cualquier posibilidad de deslizamiento pensativo o asombrado, es la imagen misma de una concentración que necesita parecerse a la alegoría de 
un trabajo, la imagen misma, para decirlo claramente, de esa mirada cerrada a lo abierto $[\ldots]$.

Para Bailly (2007), hay otras imágenes que podrían representar el pensamiento, menos pesadas, menos heroicas, mostrando paseantes descansando, "listos para seguir el vuelo de una libélula, el paso de una barca, una fumarola que se pierde en la lejanía". Yo por mi parte veo también a esas lectoras o a esos lectores sońadores, asombrados, que han inspirado a tantos pintores: a menudo han suspendido su lectura y miran hacia otro lado; no han hecho más que pasar por el libro que los lanza a aventurarse hacia otra escena.

Esa experiencia no nos es dada cada vez que tomamos un libro, pero tal vez es lo que más o menos conscientemente buscan los lectores fervientes, esos momentos de revelación, siempre fugaces, en que el mundo es como nuevo, intenso, en que encontramos lugar en él poéticamente, en que vemos lo que no veíamos, en que somos receptivos a lo que nos rodea así como a los pensamientos que nos vienen. Espera a menudo frustrada, pero volvemos a ella, en busca del ángel que nos abrirá las puertas por un instante. Puertas que son también las de nuestro mundo interior, una de cuyas facetas se dibuja, se revela de repente.

\section{Explorar la interioridad del Outro}

En el curso de mis trabajos me he nutrido mucho de los recuerdos de los lectores. Por ese sesgo pude entrar en contacto con las sensaciones que habían experimentado, con los pensamientos que nacieron gracias a un libro, con los vínculos secretos que urdieron con historias, personajes, frases o imágenes: todo ese mundo interior que se me escapaba cuando era niña y que intuía en los adultos sumergidos en los libros. Estaba en todo mi derecho, "científico", para plantear, por caminos indirectos, esas preguntas que solían venir a mí, que incluso me taladraban cuando era pequeña: “¿Qué es lo que hay en este libro, qué es lo que te hace? ¿Por qué parece que estás en otro lado? ¿A dónde te lleva? ¿Dónde está tu cabeza, en qué estás pensando?”

Por medio de mis investigaciones pude aventurarme en esa interioridad del Otro que nos fascina y que tememos -y aquí me viene a la cabeza un texto bello de David Grossman (2008), Dans la peau de Gisela [En la piel de Gisela]. Grossman (2008) dice que llegó a la conclusión de que "nos ponemos fuera del alcance -en otras palabras, nos protegemos - de 
quien sea; de la proyección de su interioridad en nosotros", de aquello que llama "el caos que reina en el prójimo". Incluso en las parejas que viven en felicidad relativa es posible que haya, instintiva, inconscientemente, un acuerdo tácito que consiste en no conocer a fondo al cónyuge. Lo mismo ocurre entre padres e hijos. Y lo mismo ocurre con el Otro en nosotros, naturalmente. "Lo que ocurre realmente en el fuero interno del Otro nos asusta" - escribe Grossman (2008), y según él la escritura sería, entre otras cosas, "un acto de protesta, de resistencia, hasta de rebelión en contra de este miedo" (GROSSMAN, 2008). A medida que escribe, al escritor se le impondría la necesidad de conocer al Otro del interior, de contactar este misterio humano. La escritura sería el único medio de lograrlo, mucho más que la fusión física, erótica, en la que a veces imaginamos que conocemos al Otro como nadie lo conoce. La enseñanza de la literatura sería, entonces, una calidad de escucha, de atención a los matices, a las singularidades, a "ese milagro único que representa cada ser humano".

Haciendo eco a la escritura, sin duda la lectura de obras literarias es también un medio para conocer al Otro del interior, para deslizarse en su piel, en sus pensamientos, sin que su caos nos inquiete demasiado, sin que nos amedrente demasiado que nos invada, sin que nos atemorice demasiado la proyección de su interioridad en nosotros. Es un medio no solamente de rebelarse contra el temor del Otro, como dice Grossman a propósito de la escritura, sino también de domesticarlo, de suavizarlo.

El valor de la lectura de obras literarias es que ésta nos permite no solamente elucidar nuestra experiencia singular, sino también expandir los límites infinitamente, permitiéndonos entrar en la piel de Gisela, de un hombre si soy mujer, del cuidador brasileńo de un rebaño o de una mujer de letras japonesa si soy europeo, de un loco si me creo sabio o de una santa si soy atea.

Blanca Calvo (2007) dice que si se topara con un genio y pudiera pedir tres deseos, elegiría la facultad de volverse invisible a voluntad, la aptitud de hablar a la perfección veinte lenguas y la capacidad de transportarse en cualquier momento del pasado o del futuro. Pero este genio, observa Blanca (2007), se encuentra en los libros: invisibles, podemos evolucionar al lado del Quijote o de Emma Bovary, pasearnos por Macondo y conversar con escritores que hayan concebido sus obras en lenguas indescifrables para nosotros.

Inmenso tesoro del arte y de la cultura, en el que podemos abrevar 
cuanto nos plazca, por poco que poseamos las llaves, por poco que no nos asuste.

\section{Una experiencia "universal”... y no obstante poco compartida}

Ahí donde la lectura nos habla de lo más hondo de la experiencia humana en forma condensada y estética, donde la esclarece, donde despierta el deseo y el pensamiento, no hay motivo alguno para que no conmueva a cualquiera. Cualquiera tiene sed de inteligencia de sí mismo y del mundo, de belleza, de poesía. Cualquiera se siente atraído, siendo nińo, por esa interioridad fascinante e intrigante, ese sitio de tantos secretos. Ahí lo más íntimo es lo más compartido, lo que nos acerca los unos a los otros.

Por lo demás, los trabajos que realicé en entornos inicialmente alejados de la cultura escrita pronto me enseńaron que la experiencia de la lectura, cuando se accedía a ella, no difería ni por pertenencia social ni por generación. En las zonas rurales francesas tanto como en los barrios marginados escuché a personas procedentes de medios de pobreza que habían tenido esta experiencia en toda su amplitud -en especial que se habían encontrado con palabras que las habían "movido", cautivado, despertado, revelado, que habían reactivado su pensamiento, transformado su representación de sí mismas y de lo que las rodeaba.

Sin embargo, son una minoría los que conocen esta experiencia, que leen libre, intensa y vívidamente. $Y$ en su mayoría se trata de mujeres y de hombres que tuvieron contacto con los libros desde su más tierna edad o que, al menos, fueron introducidos precozmente en los usos de la cultura escrita. La lectura es un arte que, más que enseñarse, se trasmite, y la transmisión en el seno de la familia es la más frecuente: lo más comun es que alguien se vuelva lector porque de nińo vio a su madre, a su padre o a su abuela con la nariz metida en los libros, porque los oyó leer historias o porque las obras que había en casa eran temas de conversación. En esas familias, las posibilidades de conocer esta experiencia lectora se dan desde el nacimiento, o casi.

En otras, por el contrario, las prohibiciones culturales se suman a las dificultades económicas y a la lejanía de lugares donde se pueda encontrar apoyo escrito. Si los niños o los adultos llegan a leer, y más aún a vivir la lectura venturosamente, es entonces gracias a un encuentro, a la cálida y discreta compañía de un facilitador que tiene afición a los libros y que, 
fortalecido por su propia experiencia, sabe hacer que estos objetos sean deseables con maña.

Ya había yo observado esto en Francia cuando realicé investigaciones en barrios marginados o en el medio rural. Después tuve la fortuna de que mis trabajos fueran bien recibidos en México y en toda América Latina. Desde hace diez ańos he viajado en muchas ocasiones a Argentina, Colombia, Uruguay, Brasil y al propio México. En esos viajes conocí a un gran número de maestros, bibliotecarios, promotores de lectura, escritores, psicoanalistas, editores, etc., con los que dialogué. De este modo descubrí otras experiencias lectoras, algunas sorprendentes experiencias literarias compartidas, desarrolladas en espacios que son objeto de conflictos armados, de crisis económicas intensas, de movimientos forzados de poblaciones o de gran pobreza. Puestas en práctica por diversos profesionales, se proponen a jóvenes procedentes de las filas de la guerrilla o de grupos paramilitares, a drogadictos que viven en la calle, a adolescentes detenidos, a niños maltratados, o a personas que han perdido su lugar de morada, etc. En pocas palabras, a nińos, adolescentes y adultos provenientes de entornos pobres, marginados, cuya cultura ha sido sojuzgada y que han crecido muy alejados de los libros.

Semejantes experiencias les son conocidas a muchos de ustedes, pero en Europa no se oye mucho hablar de ellas. Por eso me pareció importante dar a conocer las voces y las tácticas de los mediadores o de los lectores latinoamericanos en Francia, de la misma forma en que había trasladado a América Latina las experiencias de los adolescentes o de los bibliotecarios de medios rurales o de suburbios franceses. Así pues, en los últimos años he tenido intercambios continuos con quienes dan o han dado vida a una quincena de programas desarrollados en contextos difíciles. Los oí hablar, visité algunos de los sitios que animaban, leí textos que habían escrito y estudié materiales que me proporcionaron. De manera más puntual, he recabado datos sobre muchas más experiencias.

Escribí un libro a partir de su análisis, El arte de la lectura en los tiempos de crisis, que se está traduciendo y que será publicado en tres meses. Espero que Daniel no tenga inconveniente en que extraiga algunos elementos ya desde ahora para hablarles un poco más del arte de los mediadores - pues se trata efectivamente de un arte, y me viene a la memoria aquí Daoud, un joven que conocí en una biblioteca del área parisina, que dijo: "En esta biblioteca hay algo artístico ya desde el momento en que uno entra. Aquí el libro vive, respira." (PETIT, 2008) Arte del que se habla poco, 
el arte de sentir - en las dos acepciones del término en español: experimentar y oír - y de transmitir con un poco de gracia, de inventiva.

Muchos de ustedes practican cotidianamente este arte de los mediadores. La verdad, más bien debería yo decir el arte de las mediadoras, porque tanto en América Latina como en Europa son sobre todo mujeres quienes lo ejercen en nuestros días. Sin embargo, como decía el psicoanalista Jacques Lacan, hay hombres tan aptos como las mujeres - o casi tan aptos - y hay que reconocer a los hombres, a menudo jóvenes, que no temen la compañía de las mujeres y que ejercen este arte codo con codo con ellas. Es muy importante que participen en este movimiento.

Para hablar del arte de los mediadores voy a tomar un ejemplo. No de México, para no despertar celos: iré más lejos, a Argentina. Insisto en que lo traigo a colación solamente a guisa de ilustración. No se trata para nada de un modelo ni de una receta: ninguna experiencia es transferible y cada persona debe inventar con su propio ingenio sus preguntas, su estilo. Por lo demás, como verán, tomé como ejemplo una experiencia un poco especial en la que la lectura no solamente está en el centro de lo que se impulsa sino también la escritura y las artes plásticas.

\section{"En el cielo te leen poesía, en el infierno te la explican”}

En la ciudad de Bahía Blanca, en Argentina, una mujer, Mirta Colangelo, animó durante once años un taller literario y artístico en el Patronato de la Infancia a donde estos niños son llevados cuando los tribunales de menores lo deciden. De edades entre siete y catorce años, vienen de familias pobres, numerosas, rotas. Cuando Mirta comenzó a trabajar ahí, leían y escribían con dificultad, y no encontraban en ello ningún placer. Incapaces de mantener su atención, hablaban todos al mismo tiempo. Mirta recordó cuando Paulo Freire rememoró su niñez: decía que leyó el lenguaje de un árbol de mango en las diferentes estaciones, el de las ramas de los árboles, de la voz del viento, y de tantas otras cosas, y que esta lectura del mundo le había facilitado el acceso a la lectura de la letra. Para Mirta leer implicaba ya comenzar a recoger indicios para lograr la construcción de sentido. Esta construcción de sentido fue la que se dedicó a infundir a través de múltiples vías.

Con grupos pequeños de niños intentó - dice - trazar "un camino de trabajo y de disfrute, con las palabras y los silencios, con las imágenes", 
lentamente, sin prisa. Desde el inicio se cruzaron diferentes artes, diferentes lenguajes; una multitud de reproducciones iluminaron las paredes, se compulsaron libros de pintura. Les leyó muchos mitos, mucha poesía, esperando que esas lecturas darían lugar a las lecturas realizadas por ellos mismos sin haberlas puesto en palabras, que los llevarían a leer mejor el mundo y sus criaturas. Los llevó a los parques para hacer "lecturas de lenguajes no verbales", como lo dice ella:

El del tilo que se lee con los ojos en otońo y con la nariz en primavera. El de las violetas que nos regalan en invierno ramitos para todos. O el de los barcos de papel en los que los chicos escriben buenos deseos y que siempre echamos a navegar en el cordón de la vereda los días de lluvia. Nos quedamos en silencio cuando pasan los loros de chillido verde o los benteveos en contrapunto. Los escuchamos. ${ }^{2}$

"Que noten las relaciones, los vínculos, entre los lenguajes verbales y no verbales y el silencio, sin enfatizar el dar explicaciones y destacando el carácter provisorio de los hallazgos." Eso sería lo esencial para Mirta. Cita a un adolescente que escribió en una pared: "En el cielo te leen poesía, en el infierno te la explican." Para ella no es necesario ni deseable impulsar a los lectores a interpretarlo todo ni a buscar en el acto significados objetivos. Que por lo demás son provisionales y aventurados.

Cuenta también cómo los nińos y ella comenzaron a aprender coplas que se decían unos a los otros en diferentes tonos. Con el paso del tiempo los niños se atrevieron a escribir coplas, pasaron mucho tiempo trabajándolas, al punto que más adelante ganaron un concurso nacional. Recrearon obras pictóricas que encontraban en libros copiándolas o haciendo collages, con materiales que encontraban en las playas o en los jardines.

Un día, Mirta lee en voz alta un libro de Graciela Montes, Historia de un amor exagerado ${ }^{3}$. El último capítulo cuenta la preparación de un sobre "exagerado" dentro del que el protagonista decide despacharse a sí mismo como regalo de cumpleańos a su amada. El final del libro queda abierto. La historia "hizo que a los chicos les entraran las ganas de escribir

${ }^{2}$ Mirta Colangelo, "En el cielo te leen poesía, en el infierno te la explican", conferencia presentada ante el VI Congreso Internacional de Lectura, 29 Feria Internacionale del Libro de Buenos Aires : http://www.mariacristinaramos.com.ar/lecturayescritura/colangelo.html. Algunos dibujos y coplas realizados por los niños en : http://www.imaginaria.com.ar/20/7/ arte-de-los-chicos.htm. El taller se desarrolló en el Patronato de la Infancia de Bahía Blanca, institución privada que goza del apoyo financiero de la provincia de Buenos Aires.

${ }^{3}$ Historia de un amor exagerado. Buenos Aires: Ediciones Colihué. 
cartas". Mirta los acompaña entonces en una experiencia de arte-correo con desconocidos - ya que muchos de ellos no tienen a quien escribir-, con quienes intercambian dibujos, collages. Los primeros en recibir estos objetos son artistas plásticos o diseñadores de libros para niños que aceptaron participar.

En sus correos, los chicos se presentan, cuentan algo de su vida, de sus gustos. Los artistas les responden con cartas personales acompañadas de pequeñas sorpresas que incluyen obra original. Por ejemplo, Sofía, de doce años, regresó traumatizada de su casa, a la que va de cuando en cuando, después de una disputa violenta entre sus padres. La madre tuvo que ser internada, la policía detuvo al padre. Sofía no habló durante varios días. Escuchemos a Mirta: "Cuando el cartero trajo un sobre a su nombre en el que había un increíble gato-pantera que le estaba dedicado por Juan Lima, recuperó la palabra y me relató lo sucedido. Después le escribió a Juan. El gato fue su talismán durante largo tiempo.”. Yamila, por su parte, recibió del artista Hernán Haedo una máscara que permitía ver la Cruz del Sur; él le escribió: "Cuando Hernán mira la Cruz del Sur se le ocurre que vos también la estás viendo. Y si te ponés la careta para mirarla seguro que él estará allí com vos haciéndote compañía.".

A veces Mirta Colangelo lleva a los niños a la playa y lanzan botellas com mensajes, para encontrar amigos: "Después de un mes y pico una de las botellas fue hallada en una playa distante de unos $80 \mathrm{~km}$ del Puerto de White, lugar de donde había partido, por una familia que leyó la carta. Y no sólo le contestaron al niño que la había escrito sino que se acercaron hasta el Patro y como Cristian había puesto que le gustaban los chorizos y las naranjas, los trajeron y almorzaron con nosotros. Todavía Cristian mantiene correspondencia regular con la familia."

En el taller impulsado por esta mujer las palabras escritas, en un principio tan distantes, se filtraron poco a poco en la vida de estos niños y de estos adolescentes a través de toda una poética de lo cotidiano. Ahí la lectura es atención delicada a los seres y a las cosas que empiezan a ser nombradas. Se despiertan todos los sentidos y múltiples artes se entremezclan con la lectura: el dibujo, el collage, el cine (a donde los lleva en ocasiones), la música, la escritura. Todos forman parte de una misma experiencia.

Los niños trabajaron durante mucho tiempo en la fabricación artesanal de sus propios libros, conjugando también aquí varias artes, y los presentaron al museo de arte contemporáneo de su ciudad. Mirta me contó la escena en una carta: 
Los chicos leyeron textos, pasamos un CD con imágenes de los libros, ya que como cada uno es único creí oportuno que se pudieran conocer por lo menos unas cien, - están fantásticas - ; escuchamos música de cámara y repartimos plumas de loros y de palomas como souvenirs. Las habíamos juntado con los niños en un parque el domingo anterior. ¿Sabías que las cambian en otońo y se pueden encontrar debajo de los eucaliptos donde suelen dormir? [...] Vendimos casi todos los libros terminados, que fueron unos sesenta, y ya los chicos trabajadores cobraron un dinerito proporcional a lo trabajado. Compramos más papel y muchas tintas chinas de colores. Estamos muy contentos.

Yo también estuve muy contenta cuando recibí esta carta porque no sabía que los loros que duermen en las ramas de los eucaliptos "otoñan" en plumas que caen e iluminan el suelo -en mi país, los escasos pericos duermen en zoológicos. Su carta daba testimonio de una relación feliz y creativa con los libros, por parte de nińos que, sin embargo, estaban inicialmente muy lejos de ellos. Y fui muy feliz cuando recibí unos libros de los que habían hecho, cuya calidad - tanto la de los textos como la de las imágenes - me maravilló. Efectivamente, "cada ejemplar es único y no se repite, como la vida”, como dice Mirta.

Cada experiencia es también única e irrepetible: por eso les dije desde el inicio que no vieran un modelo en este bello taller, sino más bien una incitación a la libertad, a inventar sus propios caminos. En contrapunto con la obra de Mirta recordaré rápidamente el trabajo de otra mujer, del otro lado del Atlántico. Escritora y crítica de arte, Mona Thomas impulsa talleres de escritura creativa con adolescentes que atraviesan grandes dificultades escolares. Los lleva al museo del Louvre, por ejemplo, donde contemplan La balsa de la medusa, de Géricault: podría parecer algo muy distante de ellos, esta obra pintada hace cerca de doscientos años, y sin embargo les habla, esta historia de un barco que naufraga en la costa de África, donde hubo colonos que se salvaron mientras que los simples marinos fueron abandonados a su suerte en esta balsa. Después de mostrarles el cuadro, les lee en voz alta Relato de un náufrago, el texto de García Márquez, y luego les hace una propuesta de escritura como la siguiente: "Si se encontraran en una isla, ¿a quién se comerían primero, al ser que aman o a otra persona?” Y se ponen a escribir como nunca antes, en el más completo silencio.

Mona trabaja con adolescentes que, estén donde estén, siempre dicen: "Aquí no hay nada"; lo que los rodea no les dice nada, no les inspira nada. Entonces ella se esfuerza por infundirles curiosidad sobre lo que hay ahí, sobre la presencia, lo real, para que abran los ojos a lo que no veían. Trata 
también de permitirles que se apropien de otros sitios, de otras calles. En el centro de su trabajo se encuentra precisamente el hecho de sentir con el cuerpo los textos, las obras pintadas, los espacios públicos, los muelles del Sena o de un canal, etc. Todo es pretexto para abrir los ojos, para sentir, para leer y para escribir. Mona explica: "Yo abro pistas, ellos conocerán el camino. Puedo hacerlo con los parques, los edificios, por ejemplo les hablo de Versalles, les cuento que es la historia de alguien que se consideraba un dios. Que vean que todo eso viene del deseo."

\section{El arte del rodeo}

Los mediadores que he conocido aquí y allá tienen diferentes maneras de actuar en contextos de crisis: una parte de ellos dedican enteramente los espacios que animan a la lectura y a los intercambios orales que suscita; otros mezclan lectura y escritura, vistas como "dos momentos inseparables de un mismo proceso”, para hablar como Paulo Freire; otros más alternan, o combinan, como Mirta o Mona, la lectura, la escritura y otras prácticas, visitas a museos, teatro, música, danza, realización de obras gráficas o audiovisuales, etc. Sin embargo, más allá de las particularidades, varias características reaparecen en muchas experiencias que he estudiado y, tal como les decía, es un verdadero arte de la mediación el que se revela.

Estas experiencias tienen lugar a intervalos regulares, en espacios de libertad, sin calificaciones ni controles, o cuando menos sin la preocupación de una rentabilidad escolar inmediata o de resultados cuantificables. Su ambición es cultural, y no estrictamente pedagógica o terapeútica. $\mathrm{O}$, mejor dicho, aquellas y aquellos que las impulsan no han pretendido alcanzar un fin único: sus objetivos están marcados por algo indeterminado, plural. Se podría ver aquí una debilidad, pero a mí me parece, por el contrario, que la eficiencia de estos programas estriba en gran medida en que las cosas no sean demasiado fijas, en que no se puedan reducir a una función, a un campo (la educación, la formación ciudadana, la salud o la transmisión cultural, aun cuando tengan su parte), en que haya "juego" en todos los sentidos del término, fluidez, y en que se procura la posibilidad de que surja lo imprevisto. Es quizá debido a este carácter múltiple, difícil de circunscribir, plástico, flexible (aun cuando, por supuesto, haya reglas precisas que garanticen el sostenimiento de un "marco"), por lo que son particularmente aptos para enriquecer la actividad psíquica de los participantes así como sus intercambios. 
Lo que se ofrece a los que toman parte es en primer lugar una atención cálida y esmerada. Los lugares son colectivos pero cada individuo es considerado un sujeto al que se le ofrece una escucha, una disponibilidad profunda y una confianza en sus capacidades, en su creatividad. Los ritmos, o las culturas, o las adhesiones de cada uno se respetan. Se reciben y se valoran los enunciados de los niños o de los adolescentes ahí donde, en el marco académico clásico, el docente tiene tendencia más bien a poner la atención en lo que no marcha bien en la producción oral o escrita del alumno. Con frecuencia a estos jóvenes se les solicitará y se les formará para que se conviertan a su vez en pasadores de libros para otros.

En contextos críticos, el arte de los mediadores es, pues, en primer lugar, un arte de la recepción, una hospitalidad. Es también una aptitud para interrogarse sobre sí mismo: los que están comprometidos en estos programas han pensado en su propio recorrido, en su propia relación con los libros; han reflexionado, justamente, en su propia experiencia; también observan con esmero lo que ocurre durante las sesiones y elaboran su reflexión a través de la escritura o la confrontación con otros que practican el mismo arte.

El arte de los mediadores es una calidad de presencia, capacidad de estar ahí con sus cuestionamientos, su propio mundo, su estilo, su cuerpo: en los sitios de lectura que he visitado los mediadores son duchos en sus conocimientos pero están ahí también con sus sentidos, su energía (observa Juan Groisman, un joven argentino: "al principio creo que venían por nuestra energía, nuestro deseo; era lo que estaba en primer lugar"). Están ahí con sus voces que dan vida a los textos: la oralidad está en el centro de prácticamente todos los programas desarrollados en esos espacios en crisis. "La voz viva es lo opuesto de la letra muerta y de la lengua estereotipada" escribe la psicoanalista Marie-France Castarède (2002, p. 202). También dice:

[...] algunas revisiones desgarradoras deberían llevarnos a desarrollar más que nunca el espacio cultural, sitio privilegiado de la expresión de sí mismo y de la comunicación con los demás, contrapeso decisivo para el mundo de la inteligibilidad y de la ciencia tecnológica [...] Lo sensible ha sido destronado en provecho del conocimiento. Ya es hora de que regrese a su casa porque es el paraíso que hemos perdido (CASTARÈDE, 2002, p. 202).

Muchos de los mediadores que trabajan en contextos difíciles se consagran justamente a suscitar idas y venidas entre lo sensible y el lenguaje; a recuperar, tras el texto, la tierra adentro de sensaciones, de emociones, un 
movimiento, un ritmo; a permitir a los participantes entrar a la danza. Al así hacer, éstos se apoderan de fragmentos de obras leídas para apuntalar todo un trabajo de construcción o de reconstrucción de sí, aun si crecieron ajenos a los libros. No necesariamente se convertirán en grandes lectores, pero los libros ya no les repelen, ya no les asustan. La lectura deja de ser un desciframiento fastidioso, la austera faena a la que es necesario someterse para satisfacer a los adultos. Se vuelve experiencia, íntima y compartida.

No voy a decirles a través de qué procesos se opera esta reconstrucción, ni tampoco cuáles son las obras idóneas para propiciarlos. El tiempo no nos alcanzaría, ¡y además debo infundirles el deseo de leer mi libro! Me limitaré a decirles que lo que se ofrece a los que participan en estos programas es la posibilidad de dar un rodeo, que movilice el deseo y reactive el pensamiento. Ahora bien, se tiende demasiado a olvidar en estos tiempos de evaluaciones contables, de obsesión por una rentabilidad inmediata, que el rodeo es una necesidad antropológica, psíquica, y más aún en tiempos críticos. El rodeo es vital cuando de evitar el dolor o el miedo se trata en vez de enfrentarlos. Es igualmente esencial para el pensamiento y la creatividad. Dar rodeos o tomar desviaciones puede, también, constituir un preámbulo indispensable a todo verdadero aprendizaje. De otro modo los libros seguirán siendo letra muerta, aun si se aprende a descifrarlos.

No se puede tomarle gusto al aprendizaje hasta después de haber jugado mucho con la lengua, tal como tampoco podemos interesarnos en la realidad y desear modificarla hasta después de haber transitado largamente por la fantasía, por lo imaginario. No obstante, René Diatkine (1995) observó que "el interés literario [de los] malos alumnos, a punto de volverse iletrados, puede reavivarse. Los niños más grandes descubren tardíamente a veces el placer de leer, sobre todo cuando no se da en un contexto de examen [...]". Para una parte de los que han crecido lejos de la cultura escrita, los libros son símbolos de una autoridad enemiga, hasta colonizadora, que los excluye. En la escuela esta cultura y el saber formalizado pasan por encima de ellos sin tocarlos. Más expuestos a la vagancia escolar, no pueden tampoco abrevar en los textos para tamizar sus angustias o formalizar su rebelión. Pero a veces es posible una reconciliación con lo escrito a través de experiencias como las que acabo de relatar.

Por medio de un intercambio inicial gratificante y poético con un intercesor, los participantes dejan que entren en sus ensoñaciones, en su cuerpo, en su pensamiento, algunos textos, algunas imágenes, que les devuelven ecos de lo más profundo de sí mismos; leen las dolorosas páginas 
de su vida en forma indirecta y se convierten poco a poco en los narradores de su propia historia. Desarrollan su capacidad de asombro, su facultad para discernir tanto sus paisajes interiores como los que los rodean, así como para nombrarlos, pensarlos, transformarlos, compartirlos. Esa lectura va de la mano del movimiento del deseo, junto con una espera, la búsqueda de otra cosa. Ayuda a despejar dentro de sí un sitio para el Otro, con las posibilidades y los riesgos que implica todo encuentro.

Éstos son algunos de los caminos a través de los cuales he abordado algunas experiencias lectoras. Hay otras que me alegra oír evocar en este seminario. Una sola palabra más: Walter Benjamin pensaba que a fuerza de vernos sumergidos en informaciones siempre acompańadas de comentarios perdimos el arte de la narración y la facultad de intercambiar experiencias. Me gustaría pensar que estaba equivocado. Gracias a la resistencia tozuda de creadores y de pasadores de libros y de historias, que están decididos a no dejar todo el lugar al estrépito mediático y al mutismo, la experiencia lectora no se pierde y a veces se transmite a los que vivían completamente alejados de los libros. En contextos difíciles a veces apoya precisamente el arte de la narración, la facultad de explorar lo vivido y de conversar sobre la vida con una veracidad y un esmero que ningún reality show haría jamás. En ocasiones reactiva una tradición oral perdida.

Vemos cuán valioso es el arte de los mediadores que trabajan en estos contextos, y que los que escriben la historia cultural deberían tenerlo en cuenta. Lo difícil que es también, sobre todo porque supone una aptitud más: la de mover cielo y tierra para obtener los subsidios que permitan que estos programas continúen, la de mantener el rumbo y batirse sin descanso, sin dejarse desalentar demasiado, a pesar de los altibajos políticos y de los eventuales caprichos de las autoridades tutelares.

Este arte debería ser sostenido y alentado, y las iniciativas de los mediadores apoyadas, apuntaladas y multiplicadas por una voluntad política, para que se ofrezca a cualquiera la oportunidad de encontrar múltiples ecos de su experiencia humana y de descubrir otros mundos.

Gracias.

\section{Referências}

BAILLY, Jean-Christophe. Le versant animal. Paris: Bayard, 2007. 
BAUDRY, Jean-Louis. L’âge de la lecture. París: Gallimard/Haute enfance, 2000.

BERGOUNIOUX, Pierre. Comme des petits poissons. In: ZOUGHEBI, Henriette. La littérature dès l'alphabet. París: Gallimard, 2002.

BOURDIEU, Pierre; CHARTIER, Roger. La lectura: una práctica cultural (entrevista). In: CHARTIER, Roger. Pratiques de lecture, París, Payot, p. 279.

CALVO, Blanca. Deseos. In: IGLESIAS, Javier Pérez. Palabras por la lectura, Plan de lectura. Castilla: La Mancha, 2007.

CASTARÈDE, Marie-France. La Voix et ses sortilège. París: Les Belles lettres, 2000.

DIATKINE, René. Lecture et développements psychiques. Perspectives Psychiatriques, n. 481, 1995. (reimpreso en Cahiers d'A.C.C.E.S., núm. 4).

GARZO, Gustato Martín. El caballero de los brezos. In: GARZO, Gustavo Martín. El hilo azul. Madrid: Aguilar, 2001. p. 21-31.

GROSSMAN, David. Dans la peau de Gisela [En la piel de Gisela]. París: Seuil, 2008.

LARROSA, Jorge. La experiencia de la lectura. México: Fondo de Cultura Económica, 2003.

MANGUEL, Alberto. Une histoire de la lecture. París: Actes Sud, 1998.

PETIT, Michèle. Una infancia en el país de los libros. México: Océano-Travesía, 2008. ( Col. Agora)

PETIT, Michèle. El arte de leer en tiempos de crisis. México: OcéanoTravesía, 2009.

PROUST, Marcel. Sur la lecture. París: Actes Sud, 1988. 